\title{
The Effect of Store Image on Store Loyalty Mediated by Customer Satisfaction and Trust
} Robaka Shamsher

Associate Professor, CIU Business School, Chittagong Independent University (CIU), Chittagong, Bangladesh E-mail: robaka@ciu.edu.bd; robaka.shamsher@gmail.com

DOI:https://doi.org/10.38157/business-perspective-review.v3i1.330

Citation: Shamsher, R. (2021). The Effect of Store Image on Store Loyalty Mediated by Customer Satisfaction and Trust. Business Perspective Review 3(1), 54-72. DOI: https://doi.org/10.38157/business-perspective-review.v3i1.330

\section{Research Article}

\begin{abstract}
Purpose: This study aims to identify the influence of store image on store loyalty in the context of the Bangladesh retail market. It also observes the mediating roles of trust and customer satisfaction on store image and store loyalty.

Methods: This is a quantitative cross-sectional study based on survey data. Data were collected through a structured questionnaire. The study used a non-probability, convenience sampling technique. Responses from 534 supermarket shoppers were included for analysis. Partial Least Square (PLS) based Structural Equation Modeling (SEM) was used to analyze the data.

Results: The results revealed that the store image has a direct relationship with store loyalty. The study also validates an indirect relationship between store image and store loyalty via customer satisfaction and trust.

Implications: This paper contributes to the theoretical and practical knowledge to formulate effective retail marketing strategies which may affect customer loyalty. The results of the study also have a contribution to the overall development of the retailing industry of Bangladesh.

Originality: This study envisioned a unique model considering the multi-dimensional hierarchical concept of store image and customer loyalty. Additionally, this study validated the intervening role of trust between store image and store loyalty which is a pioneering attempt in this regard.

Limitations: The study would have been made more effective if other variables like service quality, store choice, purchase intention, store reputation affecting store loyalty etc. were also included. In addition, the use of non-probability sampling (convenience sampling) also restricts the generalizability of the findings.
\end{abstract}

Keywords: Store Image, Store Loyalty, Customer Satisfaction, Trust, Retail Industry.

\section{Introduction}

Bangladesh's retail industry has been moving towards the supermarket culture since the late 90s. The growth of mass industrialization, increasing employment opportunities of women, gradual cultural estrangement (Shamhser, 2014), substantial western impact on urban middle and affluent 
class (Sajib et al., 2016), shifting consumer preferences and consequential changes in consumption pattern (Farid et al., 2018) have brought momentous alterations in the shopping experience of retail consumers (Shamhser, 2014) of Bangladesh. Changing tastes and expectations of convenience-seeking mindset have been shaping the Bangladeshi consumer's shopping behavior towards aspirational and coziness were purchasing from supermarkets is believed to be an emerging matter of social status and socialization (Shamsher, 2019). These behavioral transformations of the shoppers' have been stimulating the retail managers' role to consider store loyalty as a major factor in the retailing phenomenon. The retail managers' interest in exploring this area has been driven by competitive retail pressure to win market share by creating loyalty towards a particular store (Shamsher \& Hossain, 2011; Imran, Ghani \& Rehman, 2013).

The dynamic and competitive retail landscape has compelled the retailers to distinguish themselves by creating a unique image of any particular store in the target shoppers' minds. There is evidence in the literature that store image acts as a predictor for store satisfaction (Boloemer \& Ruyter 1998) and store loyalty (Stan, 2015). It is claimed that the positive and direct effect of store image influenced store loyalty through the mediating effect of customer satisfaction (Bloemer \& Ruyter, 1998; Dullie, 2012; Guduk, 2016; Arief \& Widayatmoko, 2018). However, the significant role of trust in building the confidence of Indonesian traditional market shoppers to increase store loyalty has been emphasized by Najib and Sosianika (2019). Earlier, Bowen and Shoemaker (2003) considered trust as an essentially important element of loyalty because trust cannot be easily copied by competitors.

The changing retail environment and the diversified organized retail outlet have made shopping in Bangladesh an experience of pleasure, (Shamsher \& Hossain, 2011) and excitement where preferences are measured and judged with warmth and expertise (Shamsher \& Hossain, 2011). The supermarket concept is relatively new in Bangladesh compared to the other developed countries. Some research has been conducted on the Bangladesh supermarket sector (Shamsher \& Hossain, 2011; Shamsher \& Hossain, 2012; Shamsher, 2014). Some of these studies have examined the factors that influence customers' repurchase intention (Akter \& Ashraf, 2016) and shopping experience (Rahman \& Samiha 2019) of Bangladeshi shoppers'.

However, some of these studies explored the concept of customer satisfaction and store loyalty which were either exploratory or descriptive. Yet surprisingly, none of these studies attempted to examine the influence of store image on store loyalty theoretically or empirically in the Bangladesh retail industry from the context of the supermarket sector. Previously, Akbar (2013) and Akber (2014) examined the effect of perceived service and product quality, perceived price, and product assortment on shoppers' loyalty and shoppers' patronage intention through the mediating variable of customer satisfaction of Bangladeshi shoppers. In both studies, the area of store image has neither been acknowledged nor been operationally discussed by the author. Therefore, the concept of store image is still a singular area to be investigated in the present scenario of the Bangladesh retail market.

From a retail perspective, store image is very important because the customers always search for products or services from the shop that has a favorable image in their mind. In other words, store loyalty can be built through linking the strong image of the store with the shoppers' overall 
feelings or perception about the store and their functional and psychological assessment of it. Therefore, constructing a unique store image is one of the most crucial organizational concerns for a retailer in determining shoppers' satisfaction and loyalty. Present works of literature on Bangladesh retail market highlighted that the organized retail chain stores are booming, getting attention every day amongst the urban people of the country and some recent studies have been conducted in Bangladesh in this new arena (Shamsher \& Hossain, 2011; Shamsher \& Hossain, 2012; Akbar, 2013; Shamsher, 2014; Rahman \& Samiha 2019). However, there is still enormous opportunity for research and analysis on this ground. Additionally, the present literature on the retail industry of Bangladesh suggests that no scrupulous study has been undertaken still in Bangladesh on supermarket industries to understand the influence of store image on store loyalty. Thus, the present study, in the context of the above scenario has attempted to investigate the influence of store image on store loyalty in the retail industry of Bangladesh.

After the introduction in the $2^{\text {nd }}$ section of this study extensive literature review has been conducted along with the hypothesized relationships between the research constructs and research gap. Therefore, based on the research gap the proposed theoretical model has been developed along with the conceptual framework. In the $3^{\text {rd }}$ section research design and methodology have been discussed. In the $4^{\text {th }}$ segment, data are analyzed along with necessary figures and tables. The $5^{\text {th }}, 6^{\text {th }}$, and $7^{\text {th }}$ sections contain the discussions, conclusion, and future research agenda for this paper.

\section{Literature Review}

In this section, the literature on the related subject areas has been highlighted along with the research hypotheses, proposed model, and research gap of the study. This section defines the boundaries of the study by discussing the constructs that are to be empirically examined within the proposed research model. In reviewing the relevant literature, it should be noted that the constructs used in this study have not previously been presented in one single model (this is further discussed in the research gap). The hypotheses established by the theoretical model to be empirically tested, are also discussed in this segment. These hypotheses represent the relationships between the underlying constructs (store image, customer satisfaction, trust, and store loyalty) which are discussed in the following section.

\subsection{Store Image}

Over six decades ago, Martineau (1958) described store image as the personality of the store through which a shopper defined a store in his/her mind. He suggested two categories of store image: functional attributes and psychological attributes. Location, the assortment of products, store convenience, store layout combined the former category and psychological attributes represented the shoppers' feelings stimulated by the functional attributes of the store. Researchers have defined the concept of store image with several different store attributes (Gundala, 2010; Madan \& Verma; Biswal Sreekumar \& Panda, 2016). In this study, the researcher has considered a total of five dimensions of store image which are: Sales Personnel, Store Location, Store 
Environment, Product Attributes, and Price Aspects along with sub-elements under each dimension.

\subsection{Store Loyalty}

Store Loyalty represents a competitive advantage of the store (Thomas, 2013). In other words, in the ever-changing retail environment store loyalty leads to the competitiveness of the retailers (Kesic, Soce \& Vlasic, 2005). Store loyalty has been merely defined as consumers' commitment to the store. Store loyal customers return to the same store repeatedly to satisfy their needs. It occurs because the consumers distinguish the store from other stores and perceive that the store has the excellence to serve them. Evidence supports that store loyal shoppers are those who exhibit repurchase behavior and a commitment to re-patronize the product from the same store repeatedly in future purchases (Bloemer \& Ruyter, 1998; Eid, 2011; Inamullah, 2012).

\subsection{Relationship between Store Image and Store Loyalty}

Evidence has established that the ultimate effect of Store Image on Store Loyalty is obvious (Bloemer \& Ruyter, 1998; Perumal, 2005; Dullie, 2012; Imran, Ghani \& Rehman, 2013). Nesset, Nervik, and Helgesen (2011) revealed that change in customers' perception of store image showed a direct significant effect on shoppers' loyalty. Surprisingly, Beneke, Adams, and Solomons (2011) found no direct significant relationships between store image and loyalty for South African supermarkets which are rejected by Imran, Ghani, and Rehman (2013) as a strong correlation exist between store image and store loyalty. This was also supported by Hariyadi, Ningsih, and Away (2018) who argue that store image has a significant effect on customer loyalty among the Indonesian modern retail shoppers.

Therefore, based on the above discussion of store image and store loyalty, the study proposed the first hypothesis to be examined in the Bangladesh retail context:

$H_{1}$ : A significant relationship exists between store image and store loyalty in Bangladesh retail markets.

\subsection{Customer Satisfaction}

Customer satisfaction is the positive emotional state reached by a customer after purchasing a product or service. A customer is satisfied when he/she feels, he/she has received a buying experience expected before purchase. Retailers considered customer satisfaction as an important business strategy to retain customers. In retail, customer satisfaction emerges when the value for the product and customer service results in a transaction experience that meets or exceeds consumer expectations. The greater the customer satisfaction, the greater the repeat purchase intention of the shoppers (Ananda, Mugiono \& Hussein, 2021).

\subsection{Relationship between Store Image and Customer Satisfaction}

Substantial research has been carried out to discover the importance of Store Image for influencing Customer Satisfaction (Bloemer \& Ruyter, 1998; Theodoridis \& Chatzipanagiotou, 2009; Silva \& Giraldi, 2010; Beneke, Adams \& Solomons, 2011; Kumar \& Manjunath, 2012). It is claimed that a positive store image builds a long-term and mutually profitable relationship with 
customers and enhances satisfaction as a competitive advantage in the markets. Silva and Giraldi (2010) revealed that store image played an important role in determining customer satisfaction in a Brazilian shoe store. Guduk (2016) revealed that for traditional supermarkets in the Netherlands store image was found to increase the store satisfaction intended for more loyal consumers. However, Saad and Wahid (2017) validated that store image had no significant relationship with customer satisfaction on its own. Nonetheless, this result was voided by Watanabe Torres and Alfinito (2019) who argue that store image positively affects consumer satisfaction among Brazilian supermarket shoppers'.

Therefore, based on the above background of Store Image and Customer Satisfaction the study proposed the second hypothesis to be examined in the current retail context of Bangladesh:

$H_{2:}$ A significant relationship exists between store image and customer satisfaction in Bangladesh retail markets.

\subsection{Relationship between customer satisfaction and store loyalty}

Customer satisfaction and customer loyalty are the foundations to achieve competitive advantage for organizations and are the root to become successful in the competitive landscape. Evidence has supported that store satisfaction is the key antecedent of store loyalty (Kesic, Soce \& Vlasic, 2005). Customer delight influenced customer satisfaction and loyalty (Ali et al., 2018). Research has mentioned that satisfied customers are driven to become store loyal. Studies have confirmed the significant and direct relationship between customer satisfaction and store loyalty in retail environments. The empirical results by Chinomona and Dubihlela (2014) confirmed that customer satisfaction influenced the South African shoppers' loyalty that led to their repurchase intention. Dam and Dam (2021) disclosed that customer satisfaction had a positive relationship with customer loyalty among Vietnamese supermarket shoppers'. Najib (2021) indicated that customer satisfaction has a positive influence on customer loyalty among Indonesian traditional markets shoppers.

Therefore, based on the above discussion of customer satisfaction and store loyalty the third hypothesis is proposed to be explored in the context of the Bangladesh retail market:

$H_{3}$ : A significant relationship exists between customer satisfaction and store loyalty in Bangladesh retail markets.

\subsection{Relationship between Store Image and Store Loyalty through Customer Satisfaction:}

Empirical evidence confirmed that customer satisfaction was found to act as a mediator between store image and store loyalty in the retail market of Switzerland (Bloemer \& Ruyter, 1998), Malaysia (Dullie, 2012), South Korea (Lee, Lee \& Lee, 2015) and the Netherlands (Guduk, 2016). Correspondingly, some of the very recent studies also highlight the impact of customer satisfaction as a mediating relationship between store image and store loyalty. As such, Surya (2020) validated that store image had a positive and significant effect on store loyalty directly and indirectly through the mediation of store satisfaction. Another study by Wiardi, Hadi, and Novrianda (2020) validated that customer satisfaction had a mediated effect on the indirect relationship between store image and store loyalty. 
Therefore, based on this background the present study proposed the fourth hypothesis to be examined in the current retail context of Bangladesh:

$H_{4:}$ Customer satisfaction acts as a mediator between store image and store loyalty in Bangladesh retail markets.

\subsection{Trust}

Trust between two parties means that each party is interested in the other's welfare and neither will act without first considering the impact of its action on the other. Customers with a high level of trust in the retailers generate more sales than those with low levels of trust, intend to buy the retailers' products more in the future, and do not switch to alternatives. Hence, trust breeds the confidence the customers have in the store about its products and services. Greater store trust leads to higher store loyalty (Najib \& Sosianika, 2019). Therefore, customer trust can be considered as an important antecedent of customer loyalty.

\subsection{Relationship between Store Image and Trust}

A favorable store image can build and sustain a trusting relationship with customers. An excellent image necessarily increases consumer trust and a bad image can be damaging to a company's future. Any negative image often results in a decline in consumer trust, and any erosion in trust equals a negative hit in business growth. Trust and image go hand-in-hand and therefore need to be protected and enhanced. Trust increases as a result of perceptions of store credibility and responsibility. Therefore, trust and store image matter. Beneke et al. (2011) validated that a positive, direct and statistically significant relationship existed between store image and trust in the South African supermarket industry and concluded that higher perceptions of store image direct the way to a higher degree of consumer trust. Studies emphasized a positive relationship between store image and trust (Lehu, 2001; Chaudhuri \& Holbrook, 2001). Studies indicate that image is one of the most influential factors for building consumer trust (Lehu, 2001). Besra, Kartini, and Hasan (2015) found that retail image significantly affects customer trust in Indonesian private label products.

Therefore, based on the above discussion of store Image and trust, the fifth hypothesis is proposed to be examined in the context of the Bangladesh retail market:

H5: A significant relationship exists between store Image and trust in the Bangladesh retail markets.

\subsection{Relationship between Store Loyalty and Trust}

When a customer trusts a store, he or she has strong confidence in the quality of products and services provided by that store. Research indicated that trust acts as a major driver of customer loyalty (Chaudhuri \& Holbrook 2001). Hence, customers who are not willing to trust the marketer in a competitive marketplace are unlikely to be loyal. Customers who possess deep trust in their providers tend to continue the relationship through repeated purchases. In a retailing aspect, trust results in enduring loyalty and builds a strong relationship stronger between retailers and customers. As such, Nguyen, Leclerc, and LeBlanc (2013) established a direct relationship 
between trust and loyalty. Another study by Al-Mamun (2014) established that customer trust has a significant relationship with customer loyalty in the Malaysian supermarket industry.

Therefore, based on the above discussion on store loyalty and trust the sixth hypothesis is proposed to be examined in the context of the Bangladesh retail market:

$H_{6}$ : A significant relationship exists between store loyalty and trust in Bangladesh retail markets.

\subsection{Relationship between Customer Satisfaction and Trust}

Empirical studies authenticated a relationship between satisfaction and trust. A positive, statistically significant relationship exists between store trust and satisfaction in the South African supermarket industry (Beneke al el., 2011). Grah and Tominc (2015) validated a positive relationship between satisfaction and trust in Slovenian supermarkets. Najib and Sosianika, 2019 revealed that customer satisfaction brings trust among the traditional shoppers' of Indonesia which means that satisfied shoppers' have trust in traditional markets.

Therefore, based on the above discussion on customer satisfaction and trust the present study proposed the seventh hypothesis to be examined in Bangladesh retail context:

$H_{7}$ : A significant relationship exists between Customer Satisfaction and Trust in Bangladesh retail markets.

\subsection{Relationship between Store Image and Customer Loyalty through Trust:}

Trust is a major reason for developing a favorable attitude. Research validated the significant relationship between Store Image and Trust (Lehu, 2001). Literature on this issue confirms that a positively significant relationship exists between store loyalty and trust (Chaudhuri \& Holbrook, 2001). Liu and Liu (2015) established that store image influences brand loyalty through brand trust in the drug retailing industry. However, no study could be found investigating trust as a mediator between store image and store loyalty in the retail industry.

Therefore, in the retail context of Bangladesh, the study proposed the eighth hypothesis:

$H_{8}$ : Trust acts as a mediator between the relationship of store image and store loyalty in Bangladesh retail markets.

Based on the discussions of the relationships among the research constructs the hypotheses have been developed. Now, based on these relevant hypotheses discussed above the proposed theoretical model for this research has been developed which is shown below. In this model $\mathbf{H}_{4}$ and $\mathbf{H}_{8}$ (mediation effect) have not been shown. However, $\mathbf{H}_{4}$ and $\mathbf{H}_{8}$ (mediation effect) along with the scores have been shown and discussed separately in Data Analysis through figure 3 and figure 4. 


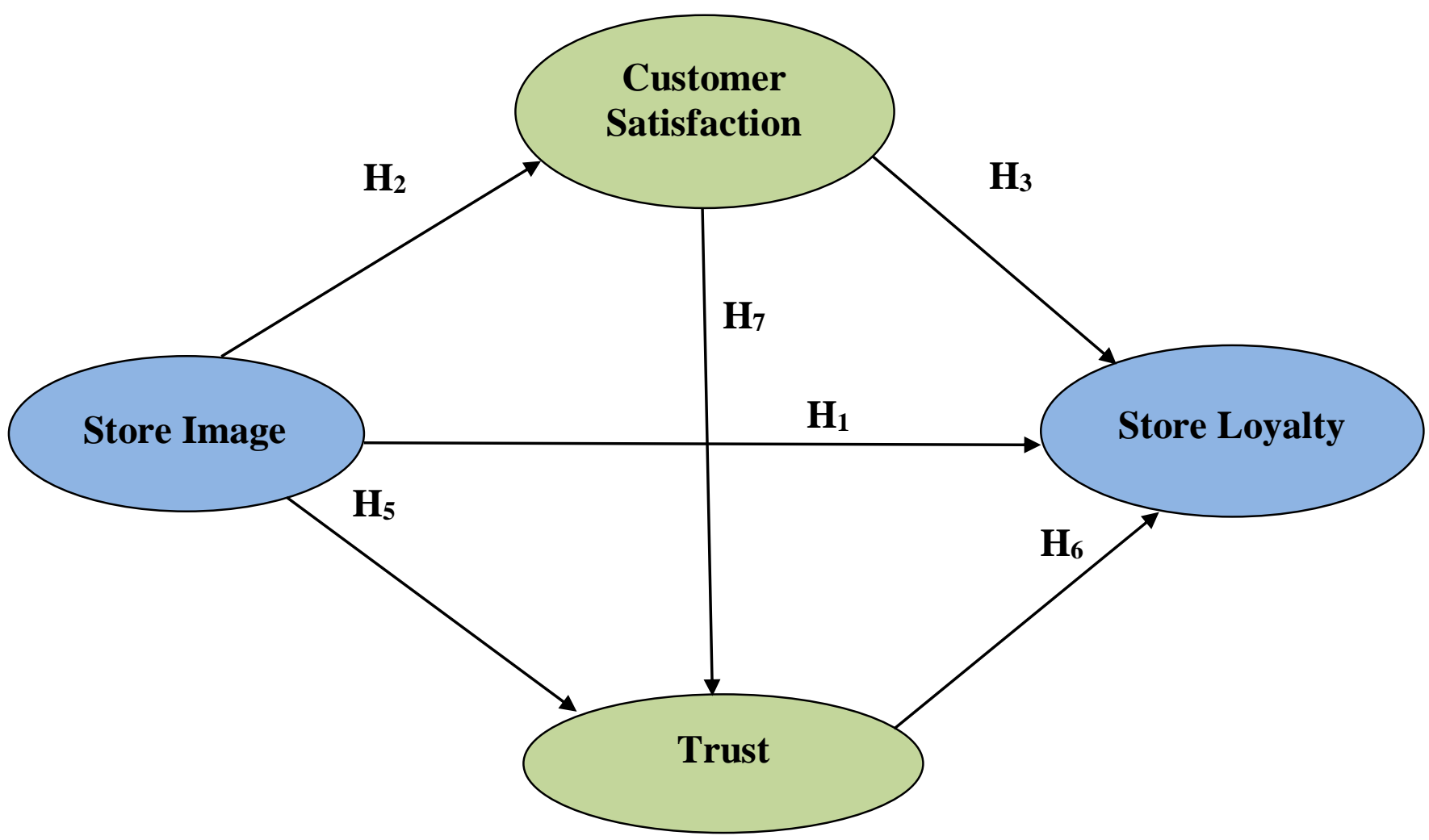

Fig. 1: Proposed Research Model

\subsection{Research Gap}

After reviewing the relevant literature, it can be posited that the research constructs described in the above discussion are essentially important in the retailing field. The previous section of the literature review has discussed the link between the constructs which indicates the importance of understanding the relationships among the various constructs. In this section, the contextual, conceptual, and methodological gaps are discussed.

Store Image has been widely studied in many different retail contexts such as the Slovenian market (Grah \& Tominc, 2015), Chinese retail enterprises (Xu-hui \& Jian, 2010), South African supermarket (Beneke, Adams \& Solomons, 2011), Indian retail industry (Madan \& Verma, 2011), Netherlands supermarket (Guduk, 2016), Indonesian retail industry (Hariyadi, Ningsih \& Away, 2018), Brazilian supermarket (Watanabe Torres \& Alfinito, 2019) and the like. However, in Bangladesh until recently very few researches have been conducted on store image. Salahuddin and Akbar (2014) determined that location is found to be the most important factor of store image in the context of a major retail store operating in Dhaka, Bangladesh. In another study, Akter and Ashraf (2016) considered store image as a factor of repurchase intention and revealed an insignificant relationship between store image and repurchase intention of Bangladeshi shoppers. In both of these studies, store image did not use as a causal study to create a link with any of the constructs that have been considered for the current study. Besides, the construct trust along with the construct customer satisfaction was not considered in any of the preceding contexts as a 
mediating variable between store image and store loyalty to verify the mediating variables. It indicates a pure contextual gap as many of the preceding studies in the world of different countries have already established relationships among store image and customer satisfaction, store image and trust, and store image and store loyalty.

Numerous academicians and practitioners have extensively discussed store image in different parts of the world such as (Martineau, 1958; Theodoridis \& Chatzipanagiotou, 2009; Silva \& Giraldi, 2010; Madan \& Verma, 2011; Guduk, 2016). The consequent effect of store image on store loyalty has been given significance in abundant studies (Bloemer \& Ruyter, 1998; Perumal, 2005; Imran, Ghani \& Rehman, 2013; Hariyadi, Ningsih \& Away, 2018). Evidence confirms that store satisfaction acts as a mediator between store image and store loyalty (Bloemer \& Ruyter, 1998; Dullie, 2012; Thomas, 2013; Guduk, 2016; Surya, 2020). Surprisingly, in Bangladesh, no such study has been carried out to examine the image of Bangladeshi stores. Additionally, the authors who have investigated store loyalty in Bangladesh retail context have neither acknowledged the concept of store image nor operationally justified its importance in the retail aspect. Hence, there is a conceptual gap as the concept of store image is still an unexplored area in the present scenario of Bangladesh retail markets.

Interestingly, in the global retail literature, numerous studies have focused on store image dimensions where these dimensions have been measured as scattered items. In the current study, the researcher has selected these scattered items as dimensions of store image from the preceding literature relevant to the Bangladesh retail scenario. Therefore, in this study store image has been considered to have five dimensions. These are store personnel, store location, store environment, product attributes, and price aspects along with sub-dimensions under each of these dimensions. Moreover, it is evident from the literature that trust has been used as a mediating variable between other constructs. However, no study was found to examine the mediating effect of trust on store image and store loyalty. This study will be the very first one to consider trust as an intervening variable in the relationship between store image and store loyalty in the retail arena of Bangladesh.

The previous studies considered store image through scattered attributes such as product, service quality, convenience, location, sales personnel reputation, cleanliness, and price (Martineau, 1958; Madan \& Verma, 2011; Biswal, Sreekumar \& Panda, 2011; Imran, Ghani \& Rehman, 2013). Store image has not been measured as a second-order hierarchical model in the preceding literature. Hence, there is a methodological gap in measuring store image as a hierarchical research model to validate its influence on store loyalty.

\subsection{Conceptual Framework}

This study is concerned with identifying the influence of store image on store loyalty within the retail domain of Bangladesh. Furthermore, for the first time relationships between store image customer satisfaction - trust, and Store loyalty have been integrated into one research model. This addresses a gap in this field as previously trust was not incorporated between store image and store loyalty as a mediator in a research model. Additionally, for the first time in the retail environment, store image has been considered as a multi-dimensional second-order hierarchical 
research construct in this model. However, many scholars have attempted to explain the relationship between store image and store loyalty, some have paid explicit attention to the role played by customer satisfaction as a mediator in this process. Nonetheless, no research has been undertaken taken yet in the retailing context to see the specific effect of customer satisfaction and trust as a mediator in one research model. Therefore, this model seeks to contribute to the existing area of knowledge by investigating the integration of customer satisfaction and trust as an important component in the image-loyalty relationship development and its significance in the retail environment of Bangladesh. The conceptual model, represented in Figure 1, shows an incorporated view of the research constructs and relationships. The proposed model examines the association between the constructs of store image, customer satisfaction, trust, and store loyalty in a single framework. Eight hypotheses $\left(\mathrm{H}_{1}, \mathrm{H}_{2}, \mathrm{H}_{3}, \mathrm{H}_{4}, \mathrm{H}_{5}, \mathrm{H}_{6}, \mathrm{H}_{7}\right.$, and $\left.\mathrm{H}_{8}\right)$ were formulated in which $\mathrm{H}_{1}$, depicts the relationship between store image and store loyalty, $\mathrm{H}_{2}$ discusses the relationship between store image and customer satisfaction, $\mathrm{H}_{3}$ deliberates the relationship between customer satisfaction and store loyalty, $\mathrm{H}_{4}$ reflects the mediating role of customer satisfaction between store image and store loyalty, $\mathrm{H}_{5}$ discusses the relationship between store image and trust, $\mathrm{H}_{6}$ discusses the relationship between store loyalty and trust, $\mathrm{H}_{7}$ discusses the relationship between customer satisfaction and trust and $\mathrm{H}_{8}$ highlights the mediating role of trust between store image and store loyalty. These hypotheses were developed to reflect a causal relationship between these underlying constructs, in which store image has been considered as the exogenous constructs while the remaining constructs are endogenous.

\section{Research Design \& Methodology}

\subsection{Data}

The study is based on primary data. It used a non-probability, convenience sampling technique for data collection as the respondents were chosen on the basis of their availability. Only local/ domestic shoppers constituted the sampling frame because local shoppers' perceptions can help to depict the loyalty status of the Bangladesh retail industry. Traditional stores or bazaars were not included in this study as the features of those shops do not cover the scope of this study. In this study, the mall intercept method was considered appropriate due to the effectiveness of this method and the easiness of access to a representative section of the respondents (Dillon, Madden \& Firtle, 1994). The shoppers were randomly approached and requested to fill up the questionnaire by themselves. A total of 695 participants filled the questionnaires. From them, 534 questionnaires were finally included for analysis, resulting in a valid response rate of $76.8 \%$. The rest were excluded due to errors and incompleteness of data. Partial Least Square (PLS) based Structural Equation Modeling (SEM) has been used to analyze the data.

\subsection{Questionnaire Design}

To collect data from the respondents a close-ended questionnaire was employed. The measurement items under the construct and scaling of the questionnaire were partially adapted from the previous works of literature (Boloemer \& Ruyter, 1998; Silva \& Giraldi, 2010; Beneke, Adams, \& Solomons, 2011; Dullie, 2012; Imran, Ghani \& Rehman, 2013; Chinomona \& Dubihlela, 
2014; Al-Mamun, 2014; Lee, Lee \& Lee, 2015; Grah \& Tominc, 2015; Guduk, 2016). The questionnaire is designed to collect the demographic information of the respondents as well as the targeted variables, such as store image, customer satisfaction, trust, and customer loyalty. The questions related to the variables were put on a 5-point Likert scale ranging from strongly disagree (1) to strongly agree (5).

The present study has considered five dimensions of store image with multiple sub-items under each dimension. The dimensions include sales personnel, store location, store environment, product attributes, and price aspect. Customer satisfaction included five aspects, namely, sales personnel, store location, store environment, product attributes, and price aspects. Trust was explored with 3 items including shoppers' faithfulness, trustworthiness, and confidence towards the store. Finally, the loyalty status of the respondents was measured in terms of regularity of purchase, continuity of future purchase, and recommending the store to others. The following table summarized the construct used in the questionnaire:

Table: 1 Summary of Construct Measures

\begin{tabular}{|l|l|l|}
\hline Constructs & $\begin{array}{l}\text { Number } \\
\text { of Items }\end{array}$ & Reference \\
\hline Sales Personnel (Store image Dimension 1) & 7 & Martineau (1958) \\
\hline Store Location (Store image Dimension 2) & 5 & Jaravaza and Chitando (2013) \\
\hline Store Environment (Store image Dimension 3) & 6 & Kyum and He (2007) \\
\hline Product Attributes (Store image Dimension 4) & 6 & Shamsher and Hossain (2011) \\
\hline Price Aspect (Store image Dimension 5) & 7 & Rahman and Jalil (2014). \\
\hline Customer Satisfaction & 5 & Bloemer and Ruyter, 1998 \\
\hline Trust & 3 & Beneke et al. (2011) \\
\hline Customer Loyalty & 3 & Shamsher and Hossain (2011) \\
\hline
\end{tabular}

\section{Results and analysis}

Data collected from the sample respondents (supermarket shoppers) were analyzed through Statistical Package for Social Sciences (SPSS) version 20 for both descriptive and inferential statistics for analyzing frequencies, mean, and standard deviation. Partial Least Square (PLS) based Structural Equation Modeling (SEM) has been used to interpret the data from the sample respondents for analyzing the relationships among the research constructs identified for this study. Structural Equation Modeling has two basic parts which are the measurement model and the structural model. (Hair, Ringle, \& Sarstedt, 2011; Wong, 2013; Samani, 2016). In this study, the author has used the reflective measurement model only as there is no item appropriate for formative measurement. After measuring the individual item reliability, internal consistency, and discriminant validity (Hulland, 1999) the author developed the structural model which evaluates the statistical significance of the path loadings and path co-efficient between each construct used in this study.

Hair, Ringle, and Sarstedt (2011) have suggested that as PLS-SEM does not assume that the data are normally distributed; hence, PLS applies nonparametric bootstrapping (Davison \& Hinkley 1997; Efron \& Tibshirani 1993). Therefore, in this study tests of significance of all paths were performed using the bootstrap re-sampling procedure. The hypotheses derived from the 
conceptual framework in Figure 1 have been analyzed in this section which is represented in Table 2. Among the eight hypotheses except for the relationship between customer satisfaction and trust showed insignificant results whilst the rest of the hypotheses were accepted by the author.

For analyzing the data first the author examined the direct relationships between the constructs, the mediation effect of customer satisfaction and trust has been shown separately. Figure 2 depicts the direct relationship between store image and store loyalty. Figure 3 represents the mediating effect of customer satisfaction between store image and store loyalty and finally figure 4 highlights the mediating effect of trust between store image and store loyalty. The following table depicts the results of the test of hypotheses from the PLS Bootstrapping:

Table: 2: Hypotheses testing and PLS Boot-Strapping output for Structural Model (SEM)

\begin{tabular}{|c|c|c|c|c|}
\hline Hypothesis & Relationship & $\begin{array}{l}\text { Beta } \\
\text { Coefficients ( }() \\
\end{array}$ & T Statistics & $\begin{array}{l}\text { Result (Accepted/ } \\
\text { Rejected) }\end{array}$ \\
\hline $\mathrm{H}_{1}$ & $\begin{array}{l}\text { Store image }->\text { store loyalty (direct } \\
\text { relationship without Mediation) }\end{array}$ & 0.5649 & 17.89 & Accepted \\
\hline $\mathrm{H}_{2}$ & store image -> Customer Satisfaction & 0.6654 & 23.60 & Accepted \\
\hline $\mathrm{H}_{3}$ & Customer satisfaction -> Store loyalty & 0.3932 & 8.20 & Accepted \\
\hline $\mathrm{H}_{5}$ & Store image $->$ trust & 0.7572 & 24.34 & Accepted \\
\hline $\mathrm{H}_{6}$ & trust $->$ store loyalty & 0.1443 & 2.54 & Accepted \\
\hline $\mathrm{H}_{7}$ & Customer satisfaction $->$ trust & 0.0503 & 1.23 & Rejected \\
\hline & \multicolumn{2}{|l|}{ Endogenous Construct } & & \\
\hline R Square & $\begin{array}{ll}\text { Customer Satisfaction } & 0.443 \\
\text { Trust } & 0.627 \\
\text { Store loyalty } & 0.413 \\
\end{array}$ & & & \\
\hline
\end{tabular}

\subsection{The Direct relationship between Store Image and Store loyalty}

In table 2 the results of the tested hypotheses are presented with their T Statistics values. The relationship between Store Image and Store Loyalty (direct relationship without Mediation) is represented in Figure 2 by using the Boot-Strapping Method which is calculated by PLS version 3.0. The results of this hypothesis show that a direct and statistically significant relationship (17.56) exists between store image (independent variable) and store loyalty (dependent variable).

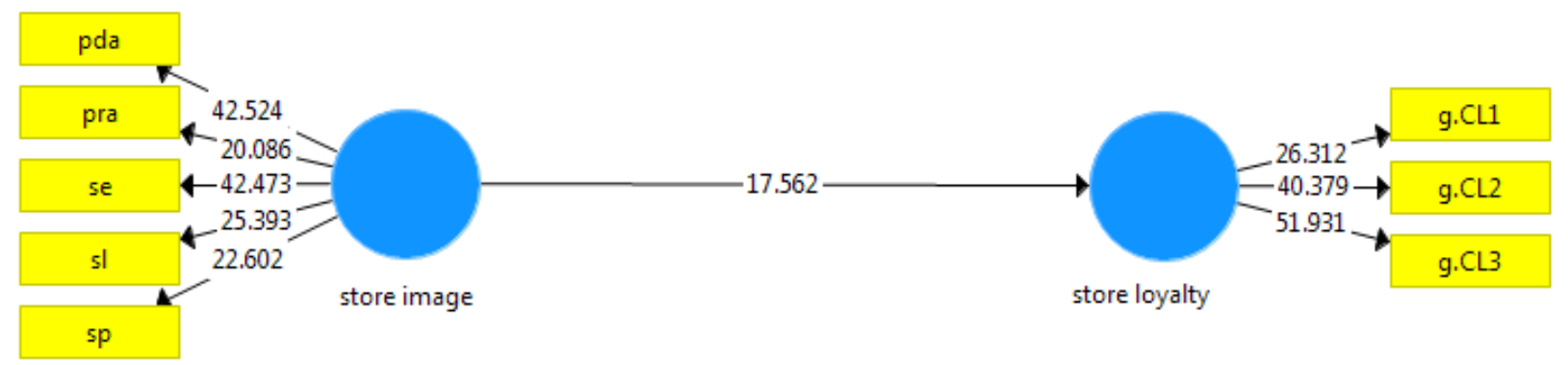

Fig 2: The Direct relationship between Store image and Store loyalty 


\subsection{Customer Satisfaction as a Mediator}

Figure 2 shows the direct and statistically significant relationship between store image store loyalty. To conduct this direct effect the researcher excludes customer satisfaction and trust from the path model and ran the bootstrapping. Then when customer satisfaction was included in the model the study results indicated that there established a statistically significant relationship (23.60) between store image (independent variable) and customer satisfaction (mediating variable). A statistical significance (8.20) has been validated between customer satisfaction (mediating variable) and store loyalty (dependent variable). In mediation, the relationship between the IV and DV is hypothesized to be an indirect effect due to the influence of a third variable MV (Customer Satisfaction as the mediator).

Therefore, when the mediating variable (MV) is included in the model, the effect of the independent variable (IV) is reduced and the effect of the mediator remains significant. It can be validated that the effect of store image on store loyalty became lower when customer satisfaction was included in the model which is shown in table 3 and figure 3 :

Table 3: Hypotheses testing for the indirect relationships

\begin{tabular}{|lllll|}
\hline Hypothesis & Relationship & $\begin{array}{l}\text { Beta } \\
\text { Coefficients (ß) }\end{array}$ & T Statistics & $\begin{array}{l}\text { Result (Accepted/ } \\
\text { Rejected) }\end{array}$ \\
\hline $\mathrm{H}_{4}$ & $\begin{array}{l}\text { Store image -> store loyalty (indirect } \\
\text { relationship } \\
\text { satisfaction as a Mediator) }\end{array}$ & 5.2915 & Accepted \\
& & & & \\
\hline
\end{tabular}

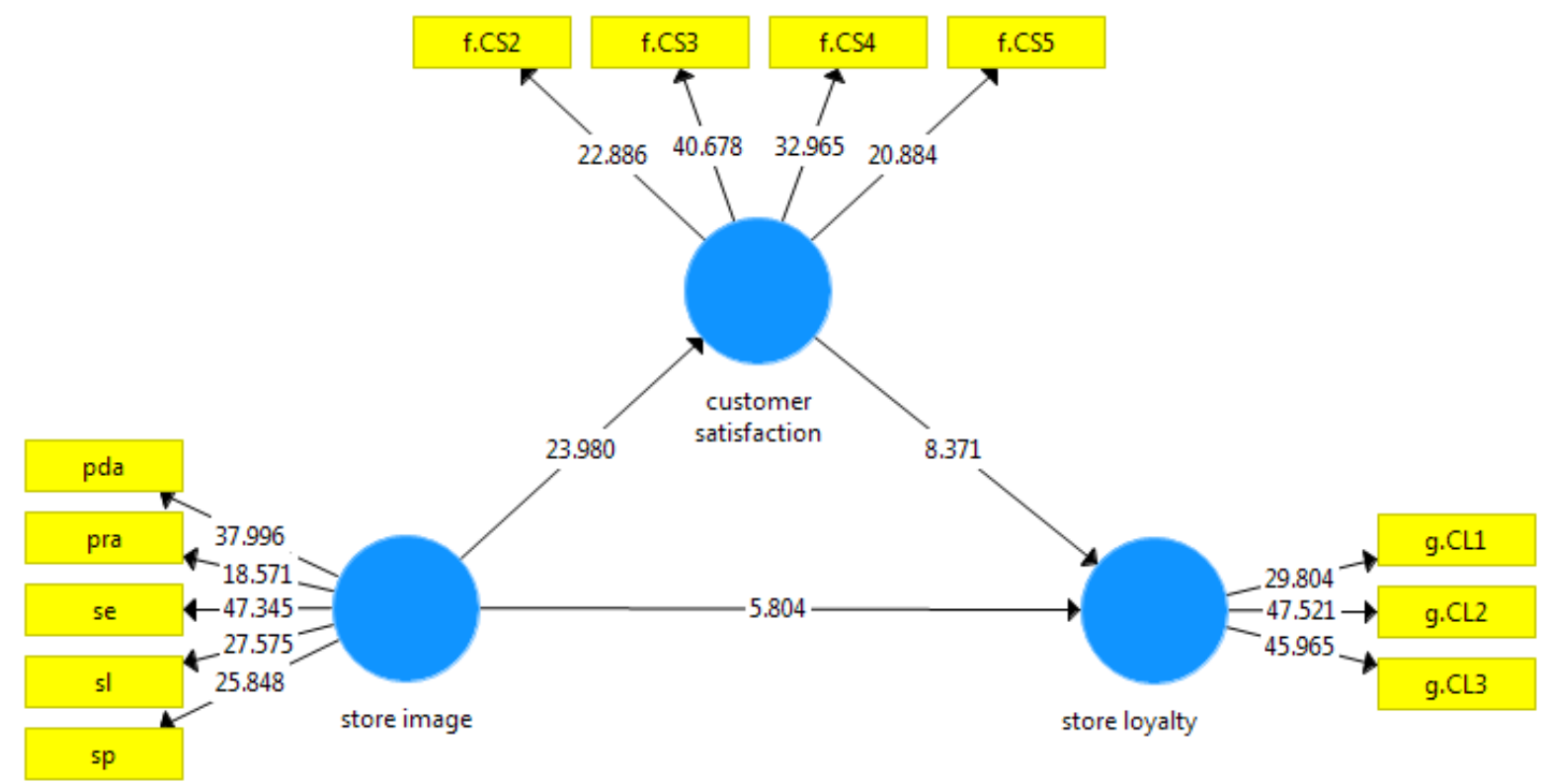

Figure 3: The mediating effect of customer satisfaction between Store Image and Store Loyalty

\subsection{Trust as a Mediator}


To see the effect of another mediating variable (MV) trust, when included in the model the results validated that there exists a statistically significant relationship (24.34) between Store Image (independent variable) and Trust (mediating variable). The model has also established a positive relationship (2.54) validation between Trust (mediating variable) and Store Loyalty (dependent variable). These results are achieved from the PLS Boot-Strapping Output. With the inclusion of trust as a mediator in the model, the effect of store image on store loyalty decreased which is shown in table 4 and figure 4 .

Table 4: Hypotheses testing for the indirect relationship between Store Image and Store Loyalty via Trust as a Mediator

\begin{tabular}{|lllll|}
\hline Hypothesis & Relationship & $\begin{array}{l}\text { Beta } \\
\text { Coefficients (B) }\end{array}$ & T Statistics & $\begin{array}{l}\text { Result (Accepted/ } \\
\text { Rejected) }\end{array}$ \\
\hline $\mathrm{H}_{8}$ & $\begin{array}{l}\text { Store image -> store loyalty (indirect } \\
\text { relationship with trust as a Mediator) }\end{array}$ & 0.4317 & 7.43 & Accepted \\
\hline
\end{tabular}

The following figure highlights the indirect relationship between Store Image and Store Loyalty via Trust as a Mediator

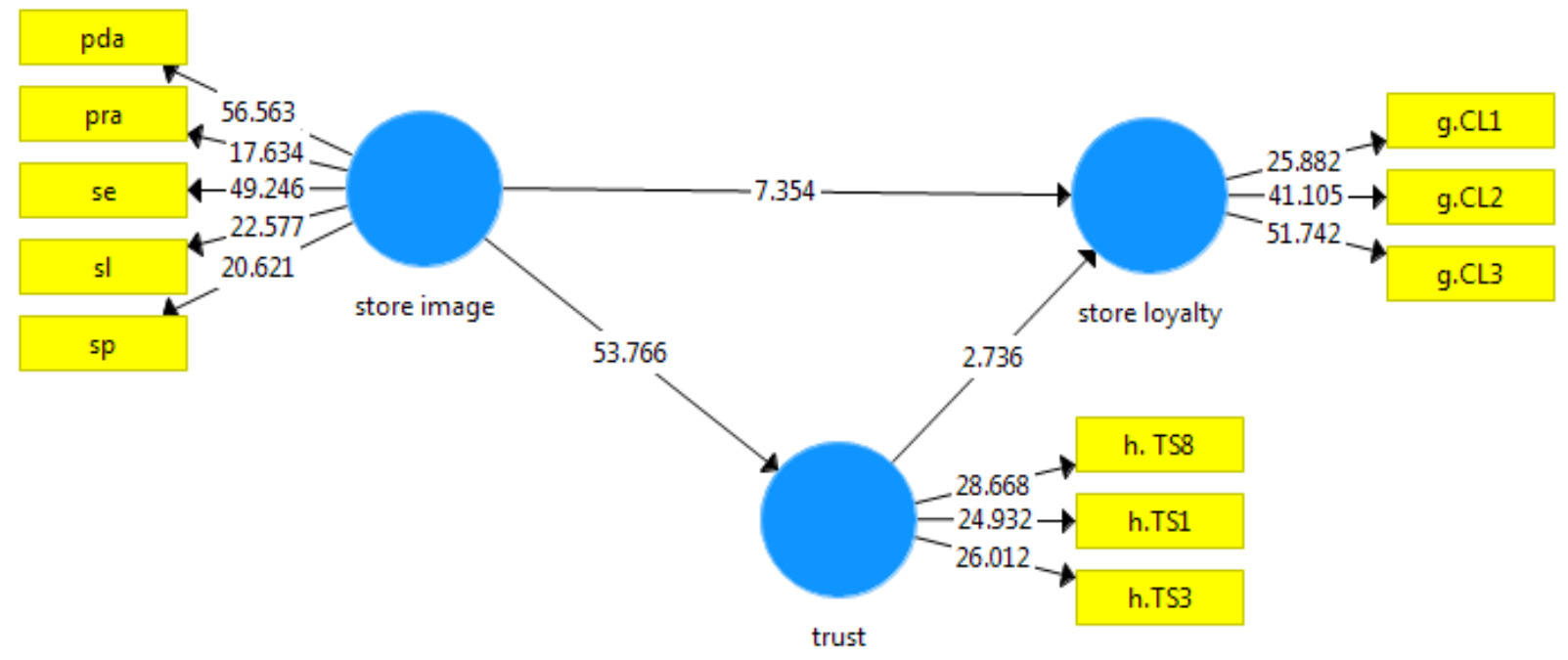

Figure 4: The mediating effect of Trust between store image and store loyalty

\subsection{Sobel test}

To confirm the significance of a mediation effect of customer satisfaction and trust, the Sobel test was conducted. Finally, Calculation of Variance Accounted For (VAF) for customer satisfaction and trust confirmed that customer satisfaction (48\%) and trust (23\%) partially mediated the link between store image and store loyalty which are discussed in detail in the next section. Therefore, the study revealed that store image has a both direct and indirect relationship with store loyalty. 


\section{Discussions}

This study developed and empirically tested a model that leads to a better understanding of the relationships between store image and Bangladeshi shoppers' store loyalty in the supermarket industry. To analyze the research objectives, the theoretical research model (Figure 1) incorporates the relationships between store image, customer satisfaction, trust, and store loyalty. Further, it examines the influence of store image on customer satisfaction, trust, and store loyalty, and finally, the mediating influence of customer satisfaction and trust on store loyalty. The results of this research largely support the hypothesized relationships proposed in the theoretical model. In particular, the results suggest that store image and store loyalty are directly and significantly related. In addition, it has been found that the constructs of customer satisfaction and trust are the important determinants of store loyalty. These results demonstrate that store image is not only necessary for the retailers to develop a favorable image in the shoppers' minds, but also essentially required for increasing satisfaction, trust, and loyalty of the retail customers in Bangladesh.

\section{Conclusion and Implications}

\subsection{Conclusion}

This paper focused on the retail sector, highlighting the importance of store image to build store loyalty. This research obtained survey-based data from Bangladeshi supermarket customers on their perceptions regarding store image, customer satisfaction, trust, and store loyalty. In the past, it was established that store satisfaction acted as a mediator between store image and store loyalty (Bloemer \& Ruyter, 1998). In line with the past research, the present study found the significant indirect effect of store image on store loyalty through customer satisfaction. Store image increases customer satisfaction, which in turn leads to more loyal shopping behavior. Store image has been measured in this study as a multi-dimensional construct with significant and direct effects on store loyalty as well an indirect effect on store loyalty via customer satisfaction and trust. Therefore, store image has been established as the antecedent for customer satisfaction, trust, and store loyalty in the Bangladesh supermarket industry.

\subsection{Implications}

This study concentrates on the perception of store image as a multi-dimensional hierarchical concept by developing an empirical model. The most significant theoretical contribution of this research is that despite having the idea of store image found in the literature as some permutation of scattered attributes, the author has considered store image as a combination of five dimensions along with sub-elements under each dimension. Store image, as the second-order hierarchical reflective measurement model used in this research, has been linked with the mediating role of customer satisfaction and trust to measure their influence on store loyalty which will make a significant academic contribution in terms of conceptualization of the research constructs and their importance to retailing business literature.

From a managerial perspective, the retail managers need to focus on store image along with customer satisfaction and trust to develop store loyal behavior of the shoppers. The image 
dimensions are highly significant for managerial perspective to develop a store's positioning strategy in their respective target markets for survival in a competitive retail landscape. This study, in addition to its contribution to the marketing literature, has important implications for the retail companies in terms of adopting strategic marketing decisions by expanding the product portfolio and aggressively focusing on branding, sales promotion, and product development to increase the flow of repeat customers.

\section{Limitations and Future Research Agenda}

The study was confined to only supermarkets. Similar studies can be conducted on the traditional retail stores of the country in the future. A comparative analysis regarding the loyalty status of traditional retail stores and supermarkets also warrants attention. Other variables like store choice, purchase intention, store commitment, service quality, etc. could be incorporated to observe different mediating and moderating effects on the current study. Future researchers may attempt to embrace more image dimensions like store reputation, sales efforts, store service, sales incentive programs, supporting facilities for a better understanding of this comprehensive construct and its significance to customer satisfaction and store loyalty. Future researches are advised to identify the effect of store image from both retailers' and consumers' perspectives for examining its changing nature over time through longitudinal studies.

Conflict of Interest: The author declares no conflict of interest.

\section{REFERENCES}

Akbar, M. M. (2013). Drivers of Retail Shoppers' Loyalty in Bangladesh. Interdisciplinary Journal of Contemporary Research in Business, 4(10), 645-662.

Akbar, M. M. (2014). A Causal Study on the Antecedents of Retail Shoppers' Repatronage Intention. European Journal of Business and Management, 6(4), 8-21.

Akter, S., \& Ashraf, E. (2016). Factors affecting repurchase intention of customers: in the context of retail chain store industry in Bangladesh. European Journal of Business and Management, 8(32), 40-47.

Ali, F., Kim, W. G., Li, J., \& Jeon, H. M. (2018). Make it delightful: Customers' experience, satisfaction, and loyalty in Malaysian theme parks. Journal of destination marketing $\mathcal{E}$ management, 7, 1-11.

Al-Mamun, A. (2014). Driving Forces of Supermarket's Consumer Trust and Loyalty: An Empirical Study in Malaysia. Australian Journal of Commerce Study SCIE Journals, 12-23.

Ananda, A., Mugiono, M., \& Hussein, A. S. (2021). The influence of store image on repurchase intention: the mediation role of perceived value and customer satisfaction. International Journal of Research in Business and Social Science (2147-4478), 10(4), 17-27.

Arief, M. \& Widayatmoko, D. H. (2018). Effect of Store Image on Loyalty Store rough Store Satisfaction in Islamic Swalayan Stores. JHSS (Journal of Humanities and Social Studies), 2(2), 34-39.

Beneke, J. Adams, O. D. and Solomons, R. (2011). An exploratory study of the relationship between store image, trust, satisfaction, and loyalty in a franchise setting. Southern African Business Review, 15(2), 59-74.

Besra, E., Kartini, D., \& Hasan, M. (2015). The role of retail image and customer trust on purchase intention of private label products. International Journal of Scientific and Technology Research, 4(4).

Biswal, S. K., Sreekumar, \& Panda, A. K. (2016). Evaluating retail store image-an empirical study in India. International Journal of Business Excellence, 9(1), 68-91. 
Bloemer, J. and Ruyter, K. (1998). On the relationship between store image, store satisfaction, and store loyalty. European Journal of Marketing, 32, 499-513.

Bowen, J. T., \& Shoemaker, S. (2003). Loyalty: A strategic commitment. The Cornell Hotel and Restaurant Administration Quarterly, 44(5-6), 31-46.

Chaudhuri, A., \& Holbrook, M. B. (2001). The chain of effects from brand trust and brand affect to brand performance: the role of brand loyalty. Journal of Marketing, 65(2), 81-93

Chinomona, R., and Dubihlela, D. (2014). Does customer satisfaction lead to customer trust, loyalty, and repurchase intention of local store brands? The case of Gauteng Province of South Africa. Mediterranean Journal of Social Sciences, 5(9), 23.

Churchill, G. A. (1995). Marketing Research Methodological Foundation (6th ed.). Orlando, Florida: The Dryden Press.

Clarke, A., \& Dawson, R. (1999). Evaluation research: An introduction to principles, methods, and practice. Sage.

Davison, A. C., \& Hinkley, D. V. (1997). Bootstrap methods and their application (Vol. 1). Cambridge university press.

de Morais Watanabe, E. A., Torres, C. V., \& Alfinito, S. (2019). The impact of culture, evaluation of store image, and satisfaction on purchase intention at supermarkets. Revista de Gestão.

Dillon, W.R., Madden, T.J. \& Firtle, N.H. (1994). Marketing research in a marketing environment (3rd Ed.). Burr Ridge, Illinois: Irwin.

Dullie, F. (2012). The relationship between store image, overall customer satisfaction, and store loyalty (Doctoral dissertation, University Malaysia Sabah).

Efron, B., \& Tibshirani, R. J. (1994). An introduction to the bootstrap. CRC press.

Eid, M.I. (2011). Determinants of e-commerce customer satisfaction, trust, and loyalty in Saudi Arabia. Journal of electronic commerce Research, 12 (1) 78-93.

Farid, M. S., Alam, M. J., Rahman, M. M., Barua, S., \& Sarker, B. (2018). Direct and associated factors influencing the growth in supermarket activity in Bangladesh. Asian research journal of arts $\mathcal{E}$ social sciences, 1-12.

Grah, M., \& Tominc, P. (2015). Relationships among Store Image and Store Loyalty in Slovenia. Naše gospodarstvo/Our economy, 61(6), 28-37.

Guduk, S. (2016). Store Image, Store Satisfaction, and Store Loyalty: A comparison between Traditional Supermarkets and Hard Discounters. Master's Thesis, MSc Economics and Business (Marketing).

Gundala, R. R. R. (2010). Retail store image: A study of the Cyprus clothing industry. International Journal of Management and Marketing Research, 3 (3), 67-81.

Hair, J. F., Ringle, C. M., \& Sarstedt, M. (2011). PLS-SEM: Indeed a Silver Bullet. Journal of Marketing Theory and Practice, 19(2), 139-152.

Hariyadi, S., Ningsih, A., \& Away, J. L. (2018). The Effect of Effect of Store Image and Store Location on Purchase Decision and Customer Loyalty of Modern Retail in the City of Samarinda. International Journal of Scientific E Technology Research, 7(9).

Hulland, J. (1999). Use of partial least squares (PLS) in strategic management research: a review of four recent studies. Strategic Management Journal, 20(2), 195-204.

Imran, M., Ghani, U., \& Rehman, K. U. (2013). Consumer perception of store image and store loyalty. Journal of Managerial Sciences, VII (1), 76.

Inamullah, K. (2012). Impact of customer satisfaction and customer retention and customer loyalty. International Journal of Scientific and Technology Research, 1 (2), 106-110.

Jaravaza, D. C., \& Chitando, P. (2013). The role of store location in influencing customers' store choice. Journal of Emerging Trends in Economics and Management Sciences, 4(3), 302-307.

Kesic, T., Soce, S., \& Vlasic, G. (2005). Image as a competitive factor of the retailing industry. In Conference Proceedings, International Conference Enterprise, 367-376.

Kim, W. K., \& He, H. (2007). A Study on Physical Environment and Consumers' Repatronage Intention. International Journal of Contents, 3(4), 30-35.

Kumar, G. A., \& Manjunath, S. J. (2012). Customer satisfaction through product, service, and store image-A study at Khadims Footwear Store. VSRD-International Journal of Business and Management Research, 2(9), 462-469.

Lee, K.H., lee, J.J. \& lee, M. (2015). Effect of Pharmacy Store Image on Customer Satisfaction and Customer Loyalty in Over-The-Counter Drug Market. Journal of Marketing Thought, 1(4), 29-44. 
Lehu, J-M. (2001), Fidelizar al Cliente, Piadós, Barcelona. [Google Scholar]

Liu, G., \& Liu, X. (2015). Influence Mechanism Research of Store Image for Consumer Brand Loyalty: Empirical Study for Medicine Retail Industry. In Proceedings of the Ninth International Conference on Management Science and Engineering Management, 1419-1431.

Madan, P., \& Verma, H. (2011). Factor Analyzing The Store Attributes To Identify Key Components Of Store Image (A Study on Some Selected Apparel Stores in India). International Journal of Marketing and Management Research, 2(1).

Martineau, P. (1958). The personality of the retail store. Harvard Business Review, No. 36, January-February, 47-55.

Najib, M. F. (2021, April). How Store Image Affects Satisfaction and Loyalty. In 2nd Annual Conference on Social Science and Humanities (ANCOSH 2020) (pp. 5-9). Atlantis Press.

Najib, M. F., \& Sosianika, A. (2019). Retail service quality, satisfaction, and trust: the key to shopper loyalty in the context of the Indonesian traditional market. International Journal of Electronic Marketing and Retailing, 10(4), 425-440.

Nesset, E., Nervik, B., \& Helgesen, Ø. (2011). Satisfaction and image as mediators of store loyalty drivers in grocery retailing. The International Review of Retail, Distribution and Consumer Research, 21(3), 267-292.

Nguyen, N., Leclerc, A., \& LeBlanc, G. (2013). The mediating role of customer trust on customer loyalty. Journal of Service Science and Management, 6(1), 96-109.

Perumal, S. (2005). A study on store image attributes and loyalty behavior. Malaysian Management Journal, 9(1 \& 2), $1-12$.

Rahman, M. K., \& Jalil, M. A. (2014). Exploring factors influencing customer loyalty: an empirical study on Malaysian hypermarkets perspective. British Journal of Applied Science \& Technology, 4(12), 1772.

Rahman, M. N., \& Samiha, N. N. R. H. Z. (2019). An Evaluation of the Factors Influencing Customers' Experience in Supermarkets of Bangladesh. Agora, 13, 22.

Saad, N. M., \& Wahid, A. Z. A. (2017). The Influence of Store Image and Corporate Image on Customer Satisfaction: A Study in Petrol Station's Convenience Store Patronage in Malaysia. In Management International Conference.

Sajib, S. S., Yaqub, M., Hosen, M. D., \& Sohad, M. K. N. (2016). Shop Till You Drop: The Impact of Westernization in Consumer Behavior in the Context of Super Shop Culture. Asian Journal of Social Sciences \& Humanities, 5(2), 222-231.

Samani, S. A. (2016). Steps in Research Process (Partial Least Square of Structural Equation Modeling. International Journal of Social Science and Business, 1(2), 55-66.

Schiffman, L. G., \& Kanuk, L. L. (2007). Consumer Behavior. Its Origins and Strategic Applications. Consumer Behavior. 9th Edition. Upper Saddle River: Pearson Education Inc, 2-4.

Shamsher, R. \& Hossain, M. J. (2011). Effect of store and product attributes influencing store loyalty: the Bangladesh retail context. The Dhaka University Journal of Business Studies, 32(2), 157-170.

Shamsher, R. \& Hossain, M. J. (2012). Consumer behavior in retailing: A comparative study between traditional and large-scale retailing. The Chittagong University Journal of Business Studies, 21, 179-197.

Shamsher, R. (2014). Consumer Shopping Preference towards Organized Retailing in Bangladesh. Metro Campus International, 155.

Shamsher, R. (2019). Analyzing the relationship between store image and store loyalty: A case study on agora from the perspective of Bangladeshi supermarket shoppers. International Journal of Research in Marketing Management and Sales, 1(2), 37-43.

Silva, T.S. \& Giraldi, J.M.E. (2010). The influence of store image on customer satisfaction: a case study of a shoe store. Brazilian Business Review, 7(2), 60-77.

Stan, V. (2015). Antecedents of customer loyalty in the retailing sector: the impact of switching costs. Journal of Applied Business Research, 31(2), 371.

Surya, A. P. (2020). The Effect of Store Image on Store Satisfaction and Store Loyalty: A Lesson from Korean-Skincare Sector in Indonesia. Scholars Journal of Economics, Business, and Management, 177-182.

Theodoridis, P. K., \& Chatzipanagiotou, K. C. (2009). Store image attributes and customer satisfaction across different customer profiles within the supermarket sector in Greece. European Journal of Marketing, 43(5/6), 708-734. 
Thomas, S. (2013). Linking customer loyalty to customer satisfaction and store image: a structural model for retail stores. The decision, 40(1), 15-25.

Wiardi, A. H., Hadi, E. D., \& Novrianda, H. (2020). Perceived Value, Store Image, and Satisfaction as Antecedents of Store Loyalty Moderated by Procedural Switching Costs. Media Ekonomi dan Manajemen, 35(1), 34-51.

Wong, K. K.-K. (2013). Partial least squares structural equation modeling (PLS-SEM) techniques using SmartPLS. Marketing Bulletin, 24(1), 1 -32.

Xu-hui, W., \& Jian, X. (2010). An Empirical Study on the Relationship between Store Image and Customer Loyalty of Transnational Retailers in China [J]. Journal of Beijing Technology and Business University (Social Science), 2.

Zikmund, W. G. (2003). Business Research Method (8th ed.). Cincinnati, Ohio: Thomson/South-Western.

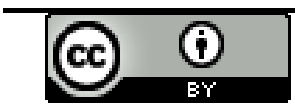

(C) 2021 by the authors. Licensee Research \& Innovation Initiative, Michigan, USA. This article is an open-access article distributed under the terms and conditions of the Creative Commons Attribution (CC BY) license (http://creativecommons.org/licenses/by/4.0/). 